\title{
Austenite Recrystallization-Precipitation Interaction in Niobium Microalloyed Steels
}

\author{
Stephanie VERVYNCKT, ${ }^{1)}$ Kim VERBEKEN, ${ }^{1,2)}$ Philippe THIBAUX, ${ }^{3)}$ Martin LIEBEHERR ${ }^{3)}$ and \\ Yvan HOUBAERT ${ }^{11}$
}

1) Department of Materials Science and Engineering, Ghent University, Technologiepark 903, B-9052 Ghent, Belgium. E-mail: Stephanie.Vervynckt@UGent.be 2) Max-Planck-Institut für Eisenforschung, Max-Planck-Strasse 1,40237 Düsseldorf, Germany. $\quad 3)$ OCAS N.V., ArcelorMittal R\&D Industry Ghent, J. F. Kennedylaan 3, B-9060 Zelzate, Belgium.

(Received on October 29, 2008; accepted on February 17, 2009)

\begin{abstract}
A good combination of strength and toughness in HSLA steels can be achieved by the addition of microalloying elements such as $\mathrm{Nb}$. Nb can retard the static recrystallization of austenite at lower temperatures by solute drag or by precipitation pinning. In this study, the recrystallization behavior of four Nb-microalloyed model alloys which were designed to show either extensive or almost no precipitation, was compared by multi-hit torsion tests and double hit compression tests. A good consistency between the different types of tests was found and the results were verified by optical micrographs. Further, by construction of softeningtime-temperature diagrams the recrystallization behavior was linked to the precipitation state of the material which was investigated by thermodynamical equilibrium calculations and by experimental observations from TEM-EDX, Inductively Coupled Plasma Mass Spectroscopy and X-ray Diffraction. Quantitative agreement between the experimental measurements and the calculations for precipitated mass fraction and precipitate composition as a function of temperature and steel composition is demonstrated.
\end{abstract}

KEY WORDS: recrystallization; microalloyed steels; precipitation; solute drag.

\section{Introduction}

The use of heavy gauge steel sheets for structural applications very often requires a combination of high yield strength and adequate toughness. The most cost effective way to realize a high yield strength and a high ductility in a low alloyed steel is grain refinement. In industrial practice, this refinement is commonly realized by thermomechanical controlled processing (TMCP). The process includes slab reheating under well defined temperatures, a high amount of hot deformation below the non-recrystallization temperature $\left(T_{\mathrm{nr}}\right)$ and accelerated cooling. The non-recrystallization temperature is defined as the temperature below which no complete static recrystallization occurs between two successive rolling passes. In practice, the grain refinement is achieved by the addition of microalloying elements such as $\mathrm{Nb}$ and $\mathrm{Ti}^{1)}$ The effect of $\mathrm{Ti}$ is more or less incontestable, i.e. the formation of TiN precipitates inhibits grain growth, whereas the role of $\mathrm{Nb}$ in retarding the austenite recrystallization in High Strength Low Alloy (HSLA) steels has been the subject of considerable interest and discussion over the past 30 years. $^{2-4)}$ Previous research ${ }^{5,6)}$ suggests that the retardation of austenite recrystallization in $\mathrm{Nb}$-containing steels results from the pinning of austenite grain boundaries and subboundaries by either niobium carbonitride precipitation and/or by niobium atoms in solid solution in austenite. Although previous investigations have provided valuable knowledge on the effect of precipitation on the recrystallization, it is presently not possible to distinguish well the effect of both mechanisms, i.e. solute drag and precipitation pinning. On the one hand, if the recrystallization kinetics would be controlled by solute drag, then it would only be necessary to consider the concentration of microalloying elements dissolved in the austenite matrix. On the other hand, if carbonitride precipitation controls the recrystallization kinetics, then the levels of carbon and nitrogen in solution would also be important. Speer and Hansen ${ }^{3)}$ investigated the austenite recrystallization in $\mathrm{Nb}$ microalloyed steels, showing that the solute drag effects on the austenite recrystallization are very small compared to the effect of carbonitride precipitation. Nevertheless, other investigators argue strongly in favor of the solute drag effect (e.g. Coladas et $\left.\mathrm{al}^{7}{ }^{7}\right)$ or of a combination of the both effects. ${ }^{8,9)}$

Thermodynamic analysis is known to be an important method for optimizing both the chemistry and process design of microalloyed steels for thermomechanical processing. So far there is relatively little experimental data on phase equilibriums of carbonitrides in commercial steels, which makes it difficult to examine the validity of the calculations with respect to experimental findings. It has already been illustrated by Inoue et al. ${ }^{10)}$ that thermodynamic equilibrium analysis of precipitates is a promising tool. These authors found good agreement between their equilibrium calculations and experimental data on the precipitated weight fraction of $(\mathrm{Nb}, \mathrm{Ti}, \mathrm{V})(\mathrm{C}, \mathrm{N})$ precipitates in hot rolled microalloyed steels. Moreover, Zou and Kirkaldy ${ }^{11)}$ showed quantitative agreement between equilibrium calculations and the experimentally determined stoichiometry of $(\mathrm{Nb}, \mathrm{Ti})(\mathrm{C}, \mathrm{N})$ precipitates in a non-deformed material. So far, the present authors found no direct comparison between the calculated equilibrium mole fraction of elements in a precipitate and experimental observations of the stoichiometry of precipitates during or after hot deformation, except a recent publication by $\mathrm{Liu}^{12)}$ who compared his calcula- 
tions with experimental data from Craven et al. ${ }^{13)}$

The objective of the present paper is to separate both retarding mechanisms, i.e. solute drag and precipitation pinning, by investigating model alloys designed to show either extensive or almost no precipitation. Moreover, the recrystallization kinetics of four $\mathrm{Nb}$-microalloyed steels during hot deformation is linked to the morphology and composition of the precipitates and the amount of $\mathrm{Nb}$-solutes found in these materials. The recrystallization kinetics were investigated combining different hot deformation testing techniques while information on the precipitation state of the material was obtained from thermodynamic equilibrium calculations and from a combination of experimental observation techniques. With this work, a contribution to the understanding of the fundamental mechanisms responsible for the retardation of austenite recrystallization in Nb-microalloyed steels is achieved.

\section{Experimental Procedure}

Four model alloys were designed and casted as $100 \mathrm{~kg}$ ingots in a Pfeiffer vacuum furnace operated under argon gas atmosphere. The chemical composition of these alloys can be found in Table 1. The C-Mn-reference alloy, without additional $\mathrm{Nb}$, represents a reference steel. The second alloy, a low $\mathrm{C}-\mathrm{Mn}-\mathrm{Nb}$ alloy containing only a few ppm $\mathrm{C}$, allowed to study the effect of $\mathrm{Nb}$ in solid solution. The third alloy $(\mathrm{C}-\mathrm{Mn}-\mathrm{Nb})$ was designed to study the effect of NbC-precipitates on the recrystallization kinetics. To have the highest fraction of $\mathrm{NbC}$ precipitates possible, a stoichiometric $\mathrm{Nb} / \mathrm{C}$-ratio of $8 / 1$ was chosen. Finally, the fourth alloy $(\mathrm{C}-\mathrm{Mn}-\mathrm{Nb}-\mathrm{N})$ was designed to study the influence of $\mathrm{N}$ on the recrystallization and precipitation behavior. The cast blocks were thermomechanically processed under conditions comparable to those during industrial steel plate rolling. This means that, after a reheating cycle of $2 \mathrm{~h}$ at $1200^{\circ} \mathrm{C}$, two pre-rolling steps with $20 \%$ of deformation each were given above $1100^{\circ} \mathrm{C}$. Before finish rolling, the plate was air cooled until a temperature of $900^{\circ} \mathrm{C}$ was reached. Finishing was performed in five passes with a total reduction of $55 \%$. After finish rolling at $820^{\circ} \mathrm{C}$, the plates were air cooled to room temperature.

Torsion test specimens were machined from the plates with the specimen long axis parallel to the transverse direction of the plate. The specimens had a gauge length of $25 \mathrm{~mm}$ and a gauge diameter of $6 \mathrm{~mm}$. The torsion tests were performed under argon atmosphere on a computerized torsion machine equipped with an induction heating system. For $T_{\mathrm{nr}}$ determination, the torsion specimens were first reheated to $1250^{\circ} \mathrm{C}$ for $5 \mathrm{~min}$. Subsequently, the samples were subjected to a series of consecutive deformations (multiple hits, strain 0.3 , strain rate $1 / \mathrm{s}$ ) separated by $20 \mathrm{~s}$ intervals, while the specimen was cooled at $1^{\circ} \mathrm{C} / \mathrm{s} .{ }^{1)}$ At least three specimens per grade were tested to ensure reproducibility of the results. For each of the deformation passes the torque and the angle of twist were measured and converted to Von Mises effective stresses s and strains $\varepsilon_{.}{ }^{14)}$

The isothermal recrystallization kinetics were determined from double hit compression tests with various interpass times. For these tests, cylindrical samples with a diameter of $5 \mathrm{~mm}$ and a height of $10 \mathrm{~mm}$ were machined by spark-erosion; the axis of the sample being parallel to the normal direction of the plate. The specimens were tested under vacuum under uni-axial conditions in a Bähr ${ }^{\mathbb{B}}$ dilatometer equipped with an induction coil and a deformation unit. After reheating for $5 \mathrm{~min}$ at $1250^{\circ} \mathrm{C}$ (same condi-
Table 1. Chemical composition of the steels (in $w t \%$ unless stated otherwise).

\begin{tabular}{cccccccc}
\hline & $\mathrm{C}$ & $\mathrm{Mn}$ & $\mathrm{Si}$ & $\mathrm{Al}$ & $\mathrm{Nb}$ & $\mathrm{Ti}$ & $\mathrm{N}$ \\
\hline C-Mn reference & 0.02 & 1.50 & 0.26 & 0.043 & - & $20 \mathrm{ppm}$ & $18 \mathrm{ppm}$ \\
lowC-Mn-Nb & $11 \mathrm{ppm}$ & 1.47 & 0.26 & 0.022 & 0.17 & $40 \mathrm{ppm}$ & $12 \mathrm{ppm}$ \\
C-Mn-Nb & 0.02 & 1.5 & 0.26 & 0.067 & 0.17 & $80 \mathrm{ppm}$ & $20 \mathrm{ppm}$ \\
C-Mn-Nb-N & 0.02 & 1.48 & 0.26 & 0.033 & 0.18 & $45 \mathrm{ppm}$ & $66 \mathrm{ppm}$ \\
\hline
\end{tabular}

tions as used for the multideformation torsion tests) and subsequent cooling at a cooling rate of $1^{\circ} \mathrm{C} / \mathrm{s}$ to a chosen deformation temperature, a first deformation pass with a strain of 0.2 and a strain rate of $0.5 / \mathrm{s}$ was given. After deformation, the stress was immediately relieved to a minimum value necessary to keep the sample in position. After different chosen waiting times, a second deformation pass (also with $\varepsilon=0.2, d \varepsilon / d t=0.5 / \mathrm{s}$ ) was applied. Subsequently, the samples were helium quenched and prepared for optical microscopy. The Béchet-Beaujard etchant was used to reveal the former austenite grain boundaries.

For the thermodynamic analysis of the precipitates, the Thermocalc $^{\circledR}$ package (database TCFE3) was used. The experimental precipitate composition and size distribution were determined on a $200 \mathrm{kV}$ JEOL JEM-2200FS Transmission Electron Microscope (TEM) in combination with an Energy Dispersive X-ray Spectrometer (EDX), using carbon extraction replicas. The total amount of niobium precipitated was analyzed by Inductively Coupled Plasma Mass Spectrometry (ICP-MS). In these experiments, a small amount of material is selectively dissolved and the resulting solution is filtered through a $20 \mathrm{~nm}$ pore size filter. The filtrate contains the dissolved Fe-matrix together with the elements in solid solution, while the filter traps the insoluble precipitates. The weight fraction of $\mathrm{Nb}$ on the filter and in the filtrate was quantitatively determined. Furthermore, the stoichiometry of the precipitates was determined by performing X-Ray Diffraction (XRD) analysis on the filters. For the radiation a $\mathrm{Cu}-\mathrm{K} \alpha$ source was used.

\section{Characterization of the Recrystallization Behavior 3.1. Determination of the Non-recrystallization Tem- perature $\left(T_{\mathrm{nr}}\right)$}

From the stress-strain curves obtained in a multideformation torsion test, the mean flow stress (MFS) corresponding to each pass can be calculated by numerical integration and plotted against the inverse of absolute temperature. The MFS is the area under each stress-strain curve divided by the pass strain. In Fig. 1, typical examples of the evolution of the mean flow stress (MFS) during multideformation testing are plotted. Two different regions can be clearly distinguished for all steels. In the high temperature region, full recrystallization takes place between two deformations and the increase in stress is solely due to the decrease in temperature. In the second region, which corresponds to deformation below $T_{\mathrm{nr}}$, only partial recrystallization or no recrystallization occurs. Here, the strain is accumulated from pass to pass, so that the stress increases more rapidly with decreasing temperature. Following the method developed by Jonas and co-workers, ${ }^{15)}$ this type of plot can be used to determine the non-recrystallization temperature, $T_{\mathrm{nr}}{ }^{16)}$ The change in slope defines this temperature, although there is some ambiguity, because the MFS vs. $1 / T$ relation is not exactly linear. As expected, the reference alloy has the lowest $T_{\mathrm{nr}}$-value of $877^{\circ} \mathrm{C}$ and the addition of $\mathrm{Nb}$ raises $T_{\mathrm{nr}}$. The lowC-Mn-Nb steel, in which most of the $\mathrm{Nb}$ is in solid so- 
lution due to the low $\mathrm{C}$ and $\mathrm{N}$ content, has a $T_{\mathrm{nr}}$ value of $920^{\circ} \mathrm{C}$. This value is lower than the $T_{\mathrm{nr}}$ of the $0.02 \mathrm{w} \% \mathrm{C}-\mathrm{Nb}$ steels with a similar $\mathrm{Nb}$-content. In these steels, $\mathrm{Nb}$ is supposed to be bonded to $\mathrm{C}$ and/or $\mathrm{N}$. The fact that both the $\mathrm{C}-\mathrm{Mn}-\mathrm{Nb}$ and the $\mathrm{C}-\mathrm{Mn}-\mathrm{Nb}-\mathrm{N}$ steels have equal $T_{\mathrm{nr}}$ temperatures of $950^{\circ} \mathrm{C}$, shows that the effect of extra $\mathrm{N}$ on $T_{\mathrm{nr}}$ is negligible.

Although $T_{\mathrm{nr}}$ is a very important temperature in industrial hot rolling mills and the multideformation testing method is universally accepted as testing procedure for the laboratory determination of $T_{\mathrm{nr}}$, the temperature value on itself does not provide a lot of fundamental information on the recrystallization-precipitation interaction. From that point of view, testing methods that can characterize the recrystallization behavior during the complete time interval between two deformation passes, could be a lot more useful. Therefore, the isothermal recrystallization behavior was studied with double deformation tests.

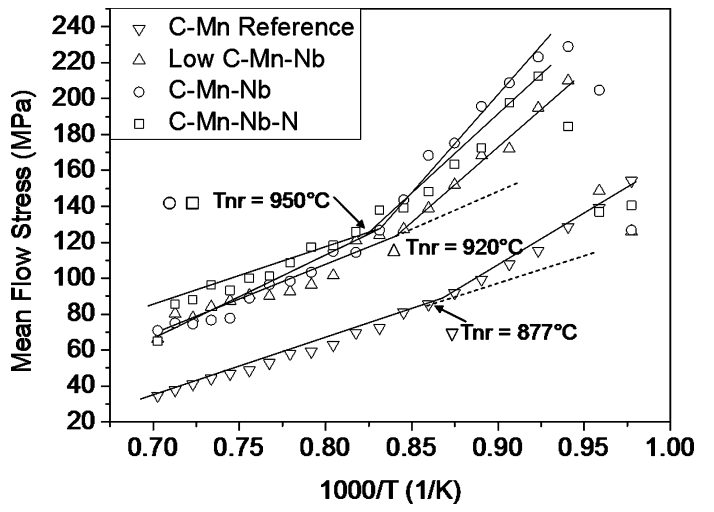

Fig. 1. Mean flow stress vs. the inverse of absolute temperature and $T_{\mathrm{nr}}$ determination for the four experimental steels.
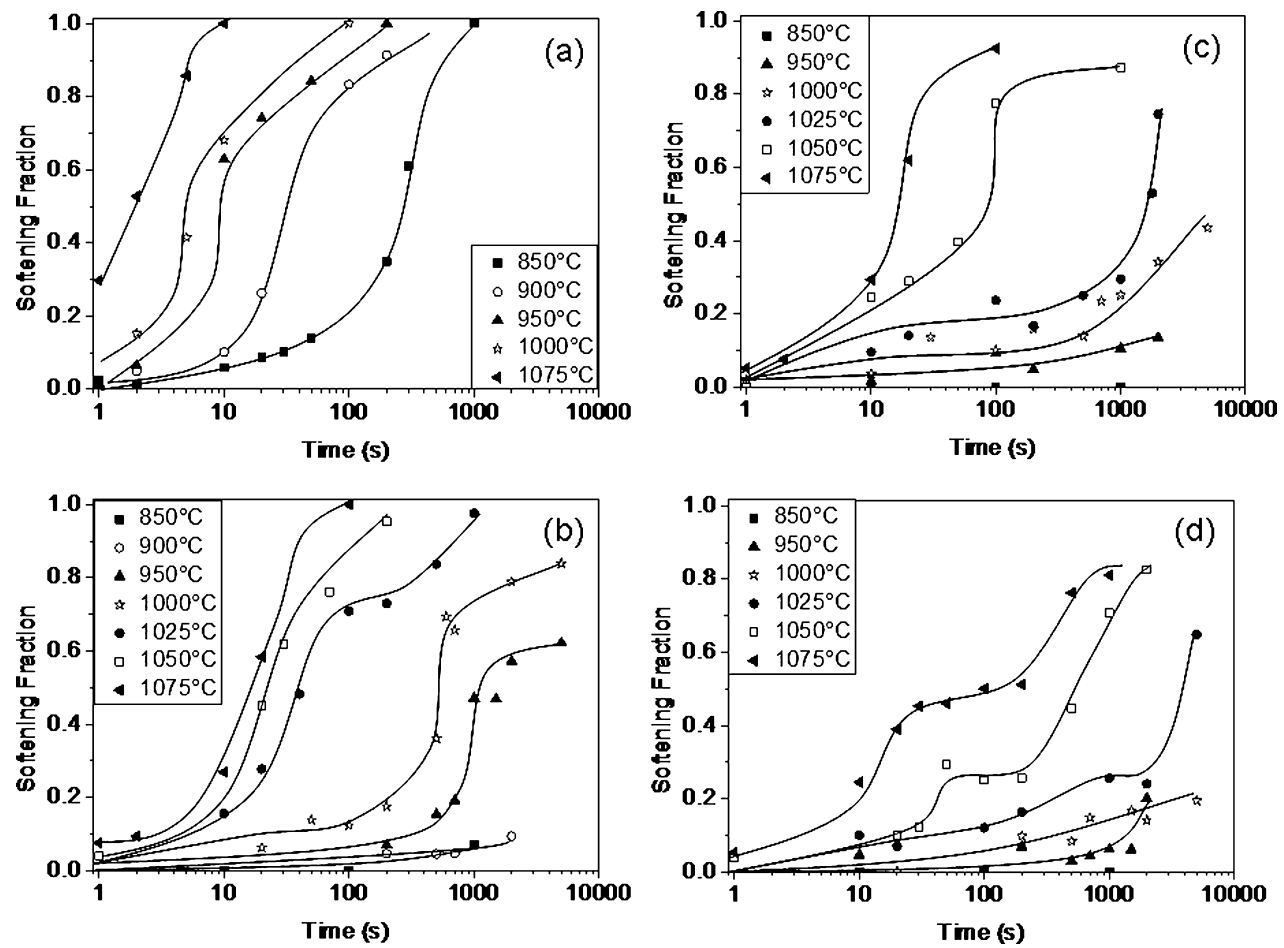

Fig. 2. Softening fractions for the experimental steels determined from double deformation tests, (a) C-Mn reference, (b) lowC-Mn-Nb, (c) C-Mn-Nb and (d) C-Mn-Nb-N.

\subsection{Characterization of the Isothermal Recrystalliza- tion Behavior}

The isothermal recrystallization kinetics were studied by means of double-hit compression tests with variable interpass times. The recrystallized fraction was determined with the help of the second stress-strain curve. If the interpass time is sufficiently long enough for full softening to occur, the second flow curve should be identical to the first flow curve. If there is no softening at all, the second flow curve should appear as an extrapolation of the first flow curve. In order to quantify the amount of softening between these extremes, the $2 \%$ offset method was used. With that method the softening effects by recovery can be neglected ${ }^{17,18)}$ and consequently the calculated softening fraction is linearly related to the statically recrystallized volume fraction. Double-hit compression tests were performed with the four experimental alloys, using deformation temperatures between 850 and $1075^{\circ} \mathrm{C}$ and interpass times between 1 and $5000 \mathrm{~s}$. The results of the softening analysis are shown in Fig. 2 while the microstructural verification of the recrystallization process is discussed in the next section.

From Fig. 2(a), it is evident that the reference alloy has the fastest recrystallization kinetics and recrystallizes fully at all testing temperatures. At temperatures of 950 and $1000^{\circ} \mathrm{C}$, the recrystallization starts $1 \mathrm{~s}$ after the first deformation and is completed in about $100 \mathrm{~s}$. At lower temperatures, $900^{\circ} \mathrm{C}$ and $850^{\circ} \mathrm{C}$, the recrystallization is retarded and starts about 10 and $50 \mathrm{~s}$ after the first deformation pass, respectively. In this case, the material is fully recrystallized after 200 and $1000 \mathrm{~s}$, respectively. It should be noted that the multideformation torsion tests described earlier, revealed a $T_{\mathrm{nr}}$ of $877^{\circ} \mathrm{C}$ for this steel composition. The interpass time during the torsion tests was $20 \mathrm{~s}$; accordingly, one would expect that the material would be fully recrystallized in $20 \mathrm{~s}$ at temperatures higher than $877^{\circ} \mathrm{C}$. The results from Fig. 2(a) show that at $900^{\circ} \mathrm{C}$ and $20 \mathrm{~s}$ interpass time the recrystallized fraction is only $27 \%$. This apparent contradiction can be explained based on the difference in grain size 
at a deformation temperature of $900^{\circ} \mathrm{C}$. At this temperature, the torsion test sample has already undergone a large number of deformation passes and accumulated a large amount of total deformation. This thermomechanical treatment should have lead to a distinct degree of grain refinement in the austenite by repeated recrystallization cycles. Alternatively, the grain size in the double-hit compression sample just before the first deformation step is expected to be relatively large due to the high reheating time and temperature, i.e. $300 \mathrm{~s}$ at $1250^{\circ} \mathrm{C}$ for both tests, and the lack of deformation prior to the double-hit test. As the grain size is reduced in the torsion samples, the recrystallization kinetics are supposed to be faster and thus the $T_{\mathrm{nr}}$ temperature, determined by the multideformation torsion tests, is expected to be lower. ${ }^{18)}$

The other alloys clearly show retarded recrystallization kinetics in comparison with the $\mathrm{C}-\mathrm{Mn}$ reference alloy which is in agreement with the values of $T_{\mathrm{nr}}$ temperatures mentioned above. The $T_{\mathrm{nr}}$ temperatures of the $\mathrm{Nb}$-added steels were also higher than the $T_{\mathrm{nr}}$ from the reference alloy. The double deformation tests seem to reveal a temporary or even permanent recrystallization stop. The times and temperatures at which this plateau appears can be linked to the precipitation state of the material and will be discussed below. The differences between the lowC- $\mathrm{Mn}-\mathrm{Nb}$ from Fig. 2(b) and C-Mn-Nb alloy from Fig. 2(c) were rather small. There was good agreement for the highest temperatures, i.e. 1075 and $1050^{\circ} \mathrm{C}$, as well as for the lowest temperature, i.e. $850^{\circ} \mathrm{C}$ : At the highest temperatures both alloys were fully recrystallized within $100 \mathrm{~s}$, and at the lowest temperature no recrystallization was observed, even after $1000 \mathrm{~s}$. For the intermediate temperatures of 950, 1000 and $1025^{\circ} \mathrm{C}$ some small differences in recrystallization behavior appeared. While at $1025^{\circ} \mathrm{C}$, for the lowC-Mn-Nb alloy, recrystallization started after $10 \mathrm{~s}$ and completed after $1000 \mathrm{~s}$, the $\mathrm{C}-\mathrm{Mn}-\mathrm{Nb}$ alloy only showed a fraction of $30 \%$ recrystallization after an interpass time of $1000 \mathrm{~s}$ at this temperature. The differences at these intermediate temperatures indicated that the $\mathrm{Nb}$ as a precipitate in $\mathrm{C}-\mathrm{Mn}-\mathrm{Nb}$ alloy had a slightly stronger retarding effect on the recrystallization kinetics than the $\mathrm{Nb}$ in solid solution in the lowC- $\mathrm{Mn}-\mathrm{Nb}$ alloy. This confirms the result of the multideformation torsion tests: $\mathrm{Nb}$ as a precipitate, $c f . \mathrm{C}-\mathrm{Mn}-\mathrm{Nb}$ alloy, is more effective for retarding the recrystallization than $\mathrm{Nb}$ in solid solution, $c f$. the lowC-Mn-Nb alloy.

The differences in recrystallization kinetics between the $\mathrm{C}-\mathrm{Mn}-\mathrm{Nb}$ alloy from Fig. 2(c) and the $\mathrm{C}-\mathrm{Mn}-\mathrm{Nb}-\mathrm{N}$ alloy from Fig. 2(d) were not expected since both steels have equal $T_{\mathrm{nr}}$ temperatures of $950^{\circ} \mathrm{C}$. At temperatures between $850^{\circ} \mathrm{C}$ and $1025^{\circ} \mathrm{C}$ the materials show similar behavior, but at $1050^{\circ} \mathrm{C}$ and $1075^{\circ} \mathrm{C}$ the $\mathrm{C}-\mathrm{Mn}-\mathrm{Nb}$ alloy recrystallizes much faster. At those high temperatures a plateau is present in the $\mathrm{C}-\mathrm{Mn}-\mathrm{Nb}-\mathrm{N}$ alloy while the $\mathrm{C}-\mathrm{Mn}-\mathrm{Nb}$ alloy follows the typical Avrami-relationship and recrystallizes fully within $100 \mathrm{~s}$. Again, precipitates have a considerable influence on the observed differences as will be discussed below.

\subsection{Microstructural Evolution}

Since the austenite recrystallization is influenced by the austenitic grain size and by the carbide and nitride precipitation, the microstructure as well as the precipitation state prior to deformation were investigated. As shown in Table 2, the grain size of the $\mathrm{C}-\mathrm{Mn}$ reference steel and the lowC-Mn-Nb steel is relatively coarse after the solution treatment at $1250^{\circ} \mathrm{C}$, while the $\mathrm{C}-\mathrm{Mn}-\mathrm{Nb}$ and the
Table 2. Austenite grain sizes and precipitate size prior to deformation.

\begin{tabular}{ccccc}
\hline & $\begin{array}{c}\text { Reheating } \\
\text { conditions }\end{array}$ & $\begin{array}{c}\text { Austenitic } \\
\text { grain size } \\
(\mu \mathrm{m})\end{array}$ & $\begin{array}{c}\text { Precipitate } \\
\text { size } \\
(\mathrm{nm})\end{array}$ & Precipitate type \\
\hline C-Mn reference & $1250^{\circ} \mathrm{C}-300 \mathrm{~s}$ & 343 & - & - \\
lowC-Mn-Nb & $1250^{\circ} \mathrm{C}-300 \mathrm{~s}$ & 261 & - & - \\
C-Mn-Nb & $1250^{\circ} \mathrm{C}-300 \mathrm{~s}$ & 152 & $40-80$ & $\mathrm{TiN},(\mathrm{Ti}, \mathrm{Nb})(\mathrm{C}, \mathrm{N})$ \\
C-Mn-Nb-N & $1250^{\circ} \mathrm{C}-300 \mathrm{~s}$ & 79 & $40-80$ & $\mathrm{TiN},(\mathrm{Ti}, \mathrm{Nb})(\mathrm{C}, \mathrm{N})$ \\
\hline
\end{tabular}

$\mathrm{C}-\mathrm{Mn}-\mathrm{Nb}-\mathrm{N}$ steels have smaller grains. The smallest austenitic grain size is observed in the $\mathrm{C}-\mathrm{Mn}-\mathrm{Nb}-\mathrm{N}$ alloy where also the finest precipitates are present, as was determined on carbon extraction replicas. The latter is in full agreement with the results of Fernandez et al. ${ }^{19)}$ who ascribe the differences in austenite grain size to the differences in Ti/ $\mathrm{N}$ ratio. A grain size of $152 \mu \mathrm{m}$ was found in the $\mathrm{C}-\mathrm{Mn}-\mathrm{Nb}$ steel with a hyperstoichiometric $\mathrm{Ti} / \mathrm{N}$ ratio, i.e. $\mathrm{Ti} / \mathrm{N}=4$. A significant smaller grain size of $79 \mu \mathrm{m}$ was found in the $\mathrm{C}-\mathrm{Mn}-\mathrm{Nb}-\mathrm{N}$ steel in which the $\mathrm{Ti} / \mathrm{N}$ ratio was only 0.7 and thus hypostoichiometric. This, together with the lower Ti supersaturation level in those hypostoichiometric $\mathrm{Ti} / \mathrm{N}$ steels, leads to an increased tendency to form smaller particles. These small particles are much more effective in pinning the grain boundaries. ${ }^{20)}$

The microstructural changes occurring during deformation and subsequent interpass times were evaluated in the quenched dilatometer samples. In Fig. 3(a), the microstructure of the lowC-Mn-Nb steel after reheating but before deformation is presented. The grains are large due to grain growth during reheating. Due to the low $\mathrm{C}$ and $\mathrm{N}$ content in this steel, all carbides and nitrides were dissolved at the used reheating times and temperatures. As a consequence grain growth was not inhibited and the grains obtained a mean size of $261 \mu \mathrm{m}$. Figure 3(b) shows the microstructure immediately after the first deformation. The recrystallization will start at the austenite grain boundaries as indicated by the fact that these boundaries are highly serrated. Figure 3(c) confirms that the recrystallized grains nucleated predominantly at austenite grain boundaries, since near the former austenite grain boundary new small grains are visible. This figure corresponds to a fractional softening of $30 \%$ as was calculated from the double deformation test (cf. Fig. 2(b)). Finally, after long interpass-times, the material is fully softened, see Fig. 3(d). The deformed $+100 \%$ recrystallized grains with a mean size of $125 \mu \mathrm{m}$ are remarkably smaller than the original grains before deformation.

\section{Characterization of the Precipitation State}

The recrystallization behavior is strongly influenced by the precipitation state of the material and thus indirectly by the chemical composition. In this section, the precipitation state of the four alloys is discussed by studying at first the equilibrium precipitation state calculated with Thermocalc and secondly by experimental data on the real precipitation state, i.e. weight fraction precipitated and morphology of the precipitates, and on the solute drag effect.

\subsection{Precipitation under Thermodynamical Equilib- rium Conditions}

The Thermocalc software was used to study the precipitation state under equilibrium conditions. For this approach, which was already used by Zou and Kirkaldy, ${ }^{11)}$ it was 


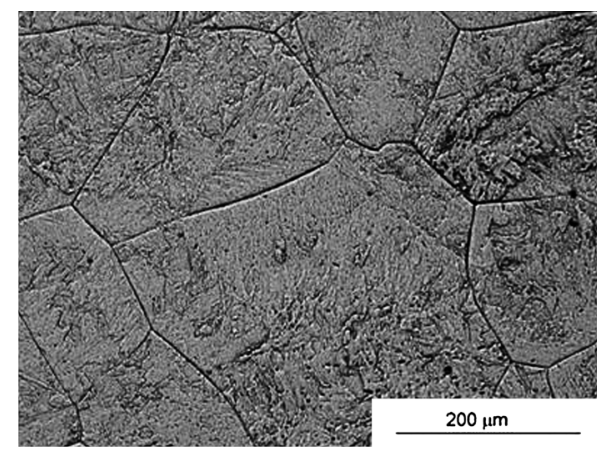

(a) Before deformation

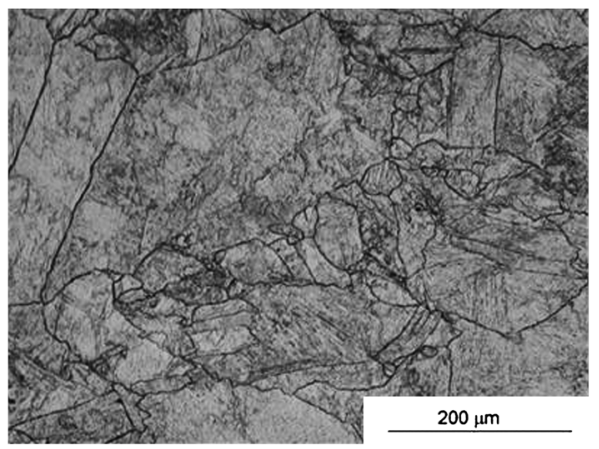

(c) 10 s after deformation (30\% softening)

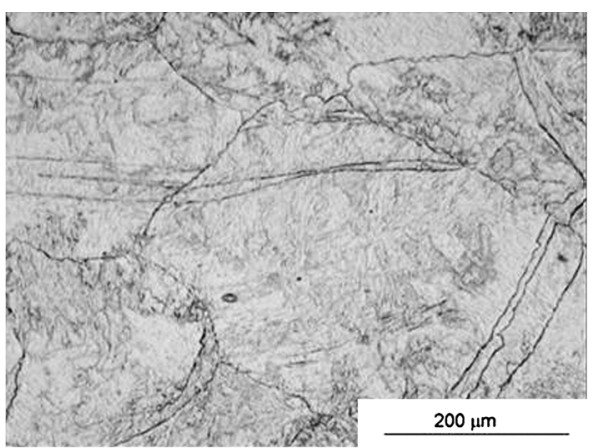

(b) 1s after deformation ( $5 \%$ softening)

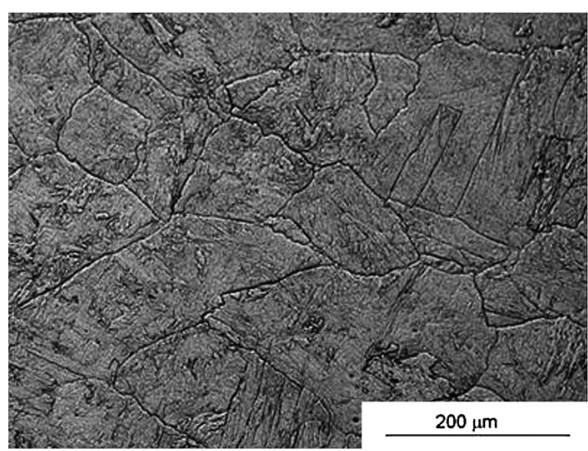

(d) 100 s after deformation (100\% softening)

Fig. 3. Austenite recrystallization behavior of microalloyed steels (lowC-Mn-Nb) before deformation and during isothermal holding after first compression $(\varepsilon=0.2, d \varepsilon / d t=0.5 / \mathrm{s})$ at $1075^{\circ} \mathrm{C}$ (etching with the Béchet-Beaujard reagent).

assumed that in the austenitic phase, i.e. the fcc\#1 phase, there was only one type of precipitate. This precipitate has a fcc-structure and is indicated as the fcc\#2 phase. This phase contains the elements $\mathrm{Ti}, \mathrm{Nb}, \mathrm{C}$ and $\mathrm{N}$ as $(\mathrm{TiNb})(\mathrm{CN})$ in a stoichiometry which varies with temperature. The results from this approximation are presented in Fig. 4. This figure shows that in the reference alloy, the precipitate starts forming at $1250^{\circ} \mathrm{C}$ and consists mainly of Ti and $\mathrm{N}$. This precipitate is rare, i.e. the maximum weight fraction in austenite is $2 \times 10^{-5} \mathrm{wt} \%$, and probably coarse since no strain induced plateau was found in the recrystallization curves from Fig. 2(a). Another possibility why this plateau was not found, is that the precipitates did not completely dissolve during reheating. The reheating temperature for the double deformation tests was $1250^{\circ} \mathrm{C}$ and this temperature equals the solubility temperature of the TiN precipitate. In that case the TiN precipitates are coarse and do not have a retarding effect on the austenite recrystallization. For the lowC-Mn-Nb alloy, the precipitate formed at high temperatures (solubility temperature $=1150^{\circ} \mathrm{C}$ ) consists also only of Ti and N. Thermodynamical simulations of the precipitation state of this steel could thus not explain the plateau in the recrystallization-time curve at temperatures between $1025^{\circ} \mathrm{C}$ and $900^{\circ} \mathrm{C}$. At those temperatures the TiN is expected to be coarse since it has formed at $1150^{\circ} \mathrm{C}$. In the $\mathrm{C}-\mathrm{Mn}-\mathrm{Nb}$ steel again $\mathrm{Ti}$ and $\mathrm{N}$ containing precipitates are formed at high temperatures. At $1050^{\circ} \mathrm{C}$ the mass fraction of the fcc\#2 increases significantly and the composition of the precipitate changes completely to $\mathrm{Nb}$ and $\mathrm{C}$ only. This change/increase should probably be interpreted as a second generation of $\mathrm{NbC}$ precipitates nucleating apart from the already existing TiN particles as Liu ${ }^{12)}$ showed in his work by considering a TiN fcc\#2 phase and a $\mathrm{NbC}$ fcc\#3 phase separately. These newly nucleated and thus small $\mathrm{NbC}$ particles are very effective in pinning the grain boundary during recrystallization. A delay in recrystallization could be seen in Fig. 2(c) at temperatures below $1050^{\circ} \mathrm{C}$, i.e. the nucleation temperature for $\mathrm{NbC}$ precipitates ( $c f$. Fig. 4(c)). Also in the $\mathrm{C}-\mathrm{Mn}-\mathrm{Nb}-\mathrm{N}$ alloy the stoichiometry of the precipitate varies with temperature, but in a different way than in the $\mathrm{C}-\mathrm{Mn}-\mathrm{Nb}$ alloy. In the $\mathrm{C}-\mathrm{Mn}-\mathrm{Nb}-\mathrm{N}$ alloy, there is a temperature range where the precipitate consists mainly of $\mathrm{Nb}$ and $\mathrm{N}$. The presence of this $\mathrm{NbN}$ dominated precipitates could explain the plateau in the curves at $1075^{\circ} \mathrm{C}$ and at $1050^{\circ} \mathrm{C}$, see Fig. 2(d). This plateau was not present in the $\mathrm{C}-\mathrm{Mn}-\mathrm{Nb}$ alloy. At temperatures of $1025^{\circ} \mathrm{C}$ and below, the stoichiometry becomes $\mathrm{NbC}$ and the recrystallization behavior becomes similar to that of the $\mathrm{C}-\mathrm{Mn}-\mathrm{Nb}$ alloy. The exact stoichiometries of the precipitates will be discussed below.

\subsection{Experimental Verification of the Precipitated Weight Fraction}

To verify the results from the thermodynamic calculations, the precipitated weight fraction of $\mathrm{Nb}$ was determined experimentally by ICP-MS at times corresponding to a softening fraction of $50 \%$, i.e. the $t_{0.5}$. This $t_{0.5}$ was directly derived from the experimental results of Fig. 2 and the numerical values for the different materials at different deformation temperatures can be found in Table 3. The $\mathrm{Nb}$ precipitated weight fraction corresponding to this $t_{0.5}$ as well as the precipitated $\mathrm{Nb}$ fraction, which was determined for the main samples, after reheating are also shown in this table. From the double deformation tests and the equilibrium calculations, one would expect that below the solubility temperature, a certain precipitated fraction is found. This fraction is found to increase with a decreasing deformation temperature.

After reheating, see Table 3, a small amount of $\mathrm{Nb}$ is precipitated $(0.01 \mathrm{wt} \%)$ in the $\mathrm{C}-\mathrm{Mn}-\mathrm{Nb}$ and in the 

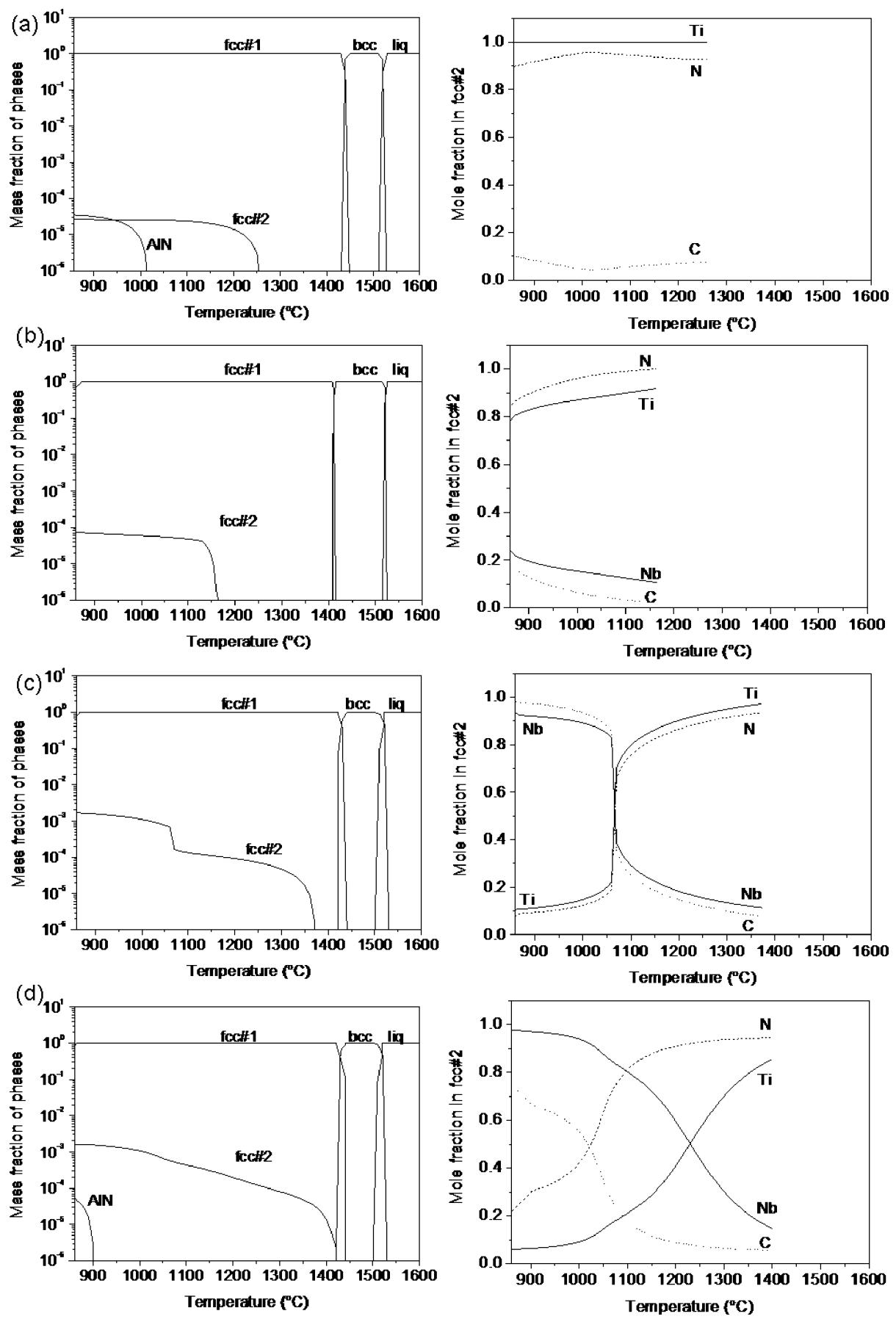

Fig. 4. Phase fraction and fcc\#2 compositions of the four experimental steels (Thermocalc), (a) C-Mn reference, (b) lowC-Mn-Nb, (c) C-Mn-Nb and (d) C-Mn-Nb-N.

$\mathrm{C}-\mathrm{Mn}-\mathrm{Nb}-\mathrm{N}$ steel. This is in agreement with the results from $\mathrm{TEM}$ measurements where $(\mathrm{Ti}, \mathrm{Nb})(\mathrm{C}, \mathrm{N})$ particles were found after reheating. At deformation temperatures of $1075^{\circ} \mathrm{C}$ almost no extra $\mathrm{Nb}$ had precipitated in these alloys. For the $\mathrm{C}-\mathrm{Mn}-\mathrm{Nb}$ alloy, this is in agreement with the results from the thermodynamical equilibrium calculations (cf. Fig. 4(c)) and with the shape of the recrystallization curve (cf. Fig. 2(c)). On the other hand, in the C-Mn-Nb-N alloy, where a clear plateau in the recrystallization curve is visible and where $\mathrm{NbN}$ particles were expected according to the equilibrium calculations, only a small amount of extra $\mathrm{Nb}$ was precipitated. The amount precipitated is $0.015 \mathrm{wt} \%$ at $1075^{\circ} \mathrm{C}$ in comparison with $0.01 \mathrm{wt} \%$ after reheating. It is possible that this small amount of precipitates is sufficient to cause the temporary recrystallization
Table 3. Precipitated mass fraction of $\mathrm{Nb}$ as experimentally determined by ICP-MS. (The mass fractions are determined at times and temperatures corresponding to the $t_{0.5}$ ).

\begin{tabular}{|c|c|c|c|}
\hline & lowC-Mn-Nb & $\mathrm{C}-\mathrm{Mn}-\mathrm{Nb}$ & $\mathrm{C}-\mathrm{Mn}-\mathrm{Nb}-\mathrm{N}$ \\
\hline After reheating & - & $\mathrm{Nb}_{\text {prec }}=0.01 \mathrm{wt} \%$ & $\mathrm{Nb}_{\text {prec }}=0.01 \mathrm{wt} \%$ \\
\hline $\mathrm{T}_{\text {def }}=1075^{\circ} \mathrm{C}$ & $\mathrm{t}_{0.5}=17 \mathrm{~s}$ & $\mathrm{t}_{0.5}=18 \mathrm{~s}$ & $\mathrm{t}_{0.5}=200 \mathrm{~s}$ \\
& - & $\mathrm{Nb}_{\text {prec }}=0.013 \mathrm{wt} \%$ & $\mathrm{Nb}_{\text {prec }}=0.015 \mathrm{wt} \%$ \\
\hline $\mathrm{T}_{\text {def }}=1050^{\circ} \mathrm{C}$ & $\mathrm{t}_{0.5}=22 \mathrm{~s}$ & $\mathrm{t}_{0.5}=63 \mathrm{~s}$ & $\mathrm{t}_{0.5}=500 \mathrm{~s}$ \\
& $\mathrm{Nb}_{\text {prec }}=0.012 \mathrm{wt} \%$ & $\mathrm{Nb}_{\text {prec }}=0.02 \mathrm{wt} \%$ & $\mathrm{Nb}_{\text {prec }}=0.04 \mathrm{wt} \%$ \\
\hline $\mathrm{T}_{\text {def }}=1025^{\circ} \mathrm{C}$ & $\mathrm{t}_{0.5}=40 \mathrm{~s}$ & $\mathrm{t}_{0.5}=1400 \mathrm{~s}$ & $\mathrm{t}_{0.5}=4000 \mathrm{~s}$ \\
& $\mathrm{Nb}_{\text {prec }}=0.016 \mathrm{wt} \%$ & $\mathrm{Nb}_{\text {prec }}=0.04 \mathrm{wt} \%$ & - \\
\hline $\mathrm{T}_{\text {def }}=1000^{\circ} \mathrm{C}$ & $\mathrm{t}_{0.5}=580 \mathrm{~s}$ & $\mathrm{t}_{0.5}=7000 \mathrm{~s}$ & $\mathrm{t}_{0.5}=10000 \mathrm{~s}$ \\
& $\mathrm{Nb}_{\text {prec }}=0.03 \mathrm{wt} \%$ & $\mathrm{Nb}_{\text {prec }}=0.06 \mathrm{wt} \%$ & - \\
\hline $\mathrm{T}_{\text {def }}=950^{\circ} \mathrm{C}$ & $\mathrm{t}_{0.5}=1300 \mathrm{~s}$ & $\mathrm{t}_{0.5}>10000 \mathrm{~s}$ & $\mathrm{t}_{0.5}>10000 \mathrm{~s}$ \\
& $\mathrm{Nb}_{\text {prec }}=0.03 \mathrm{wt} \%$ & - & - \\
\hline
\end{tabular}



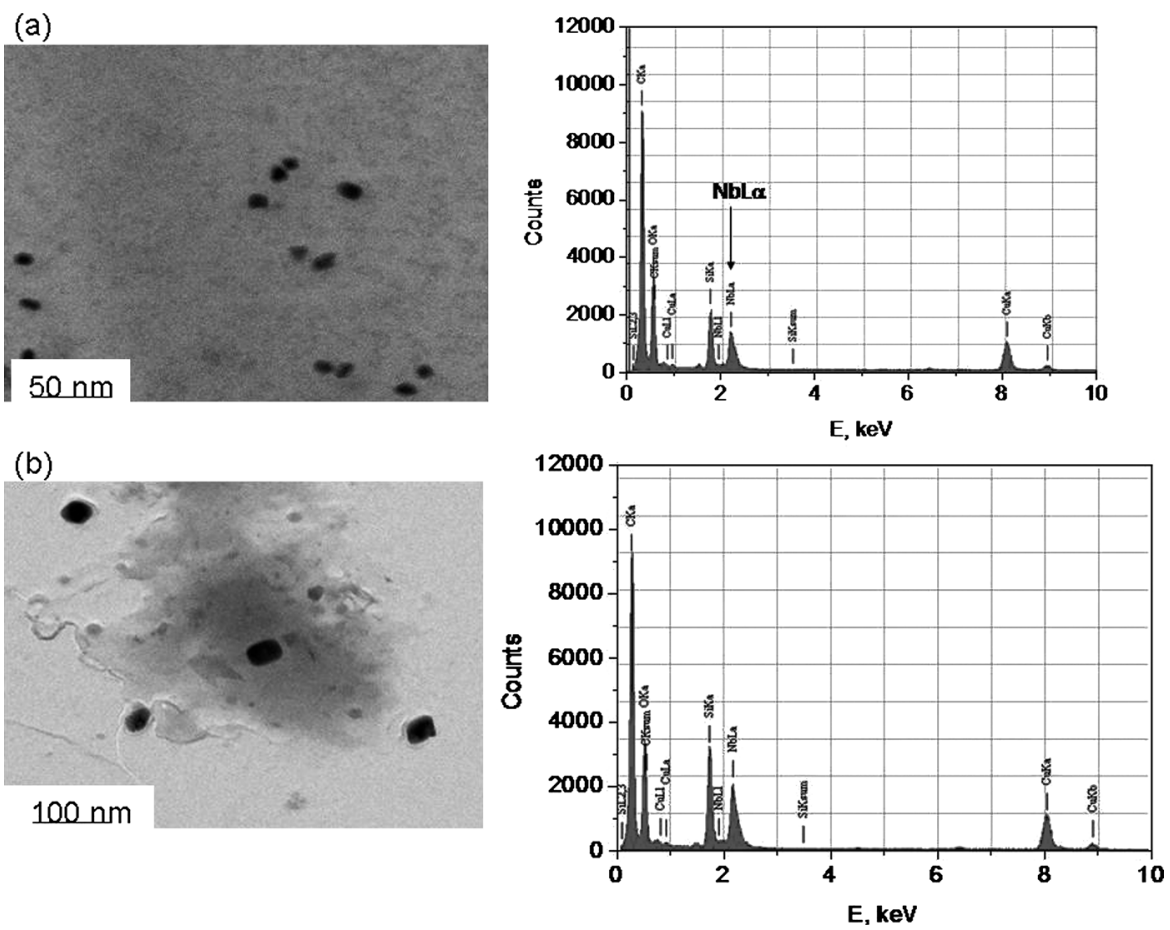

Fig. 5. TEM-EDX measurements on extraction replicas show the presence of small $\mathrm{NbC}$ precipitates in the lowC-Mn-Nb alloy after double deformation. (a) $T_{\text {def }}=1000^{\circ} \mathrm{C}$, interpass-time $=580 \mathrm{~s}$, (b) $T_{\text {def }}=950^{\circ} \mathrm{C}$, interpasstime $=1300 \mathrm{~s}$

stop but it is also possible that the precipitated fraction measured on the ICP-MS filter underestimates the true precipitated fraction if small precipitates have passed through the filter and were thus not measured. At $1050^{\circ} \mathrm{C}$, no extra precipitates were observed in the low $\mathrm{C}-\mathrm{Mn}-\mathrm{Nb}$ alloy, while the amount of $\mathrm{Nb}$ precipitated increased to $0.02 \mathrm{wt} \%$ and even to $0.04 \mathrm{wt} \%$ in the $\mathrm{C}-\mathrm{Mn}-\mathrm{Nb}$ alloy and in the $\mathrm{C}-\mathrm{Mn}-\mathrm{Nb}-\mathrm{N}$ alloy, respectively. This higher fraction of $\mathrm{Nb}$ precipitated causes an extra increase in $t_{0.5}$. The stoichiometry of the precipitates responsible for the delay will be discussed in the next section. At $1000^{\circ} \mathrm{C}$ also in the lowC$\mathrm{Mn}-\mathrm{Nb}$ alloy a precipitated weight fraction of $0.03 \mathrm{wt} \%$ was found. With TEM it was proven that these precipitates, which were found to be $\mathrm{NbC}$ precipitates, are rather small. Their mean size at $1000^{\circ} \mathrm{C}$ was $15 \mathrm{~nm}$ while they had grown to $40 \mathrm{~nm}$ at $950^{\circ} \mathrm{C}$, see Fig. 5. These precipitates were not expected based on the Thermocalc simulations, although its actual presence could explain the delay in the recrystallization curve at $1000^{\circ} \mathrm{C}$. Moreover, it seems to be unlikely to precipitate out $0.03 \mathrm{wt} \%$ of $\mathrm{Nb}$ as $\mathrm{NbC}$ since this steel contains only $0.0011 \mathrm{wt} \%$ of $\mathrm{C}$, leading to a maximum fraction of $0.0085 \mathrm{wt} \%$ of $\mathrm{Nb}$ precipitated. A possible explanation for this discrepancy could be the presence of other $\mathrm{Nb}$ containing precipitates, such as $\mathrm{Nb}_{2} \mathrm{C}$, $\mathrm{Fe}_{2} \mathrm{Nb}$ or even $\mathrm{Fe}_{3} \mathrm{Nb}_{3} \mathrm{C}$. These precipitates were regularly found in ferritic stainless steels ${ }^{21,22}$ with $\mathrm{Nb} / \mathrm{C}$ ratios of at least $30 / 1$, but were never reported in microalloyed steels, i.e. steels in which the $\mathrm{Nb} / \mathrm{C}$ ratio is usually smaller than the stoichiometric ratio of $8 / 1$. The $\mathrm{Nb} / \mathrm{C}$ in the lowC-Mn-Nb steel used in this work is $145 / 1$, so it is not unthinkable that $\mathrm{Nb}$-precipitates, other than the stoichiometric $\mathrm{NbC}$, had been formed. The exact stoichiometry of the precipitates in those steels is studied more in detail in the next section.

\subsection{Stoichiometry of the Precipitates Measured by XRD}

The results of the experimentally determined weight fractions demonstrated some differences between the precipitation state of the $\mathrm{C}-\mathrm{Mn}-\mathrm{Nb}$ and the $\mathrm{C}-\mathrm{Mn}-\mathrm{Nb}-\mathrm{N}$ alloy. At a temperature of $1050^{\circ} \mathrm{C}$, the amount of $\mathrm{Nb}$ precipitated in the $\mathrm{C}-\mathrm{Mn}-\mathrm{Nb}-\mathrm{N}$ alloy was remarkably higher than the amount of $\mathrm{Nb}$ precipitated in the $\mathrm{C}-\mathrm{Mn}-\mathrm{Nb}$ alloy. Thermodynamic equilibrium calculations ascribed the higher fraction of $\mathrm{Nb}$ precipitated in the $\mathrm{C}-\mathrm{Mn}-\mathrm{Nb}-\mathrm{N}$ alloy to the formation of $\mathrm{NbN}$ and/or $\mathrm{NbCN}$. To prove the existence of the $\mathrm{NbN}$, the stoichiometry of the present precipitates is determined. So far, researchers determined the stoichiometry of the complex $(\mathrm{Nb}, \mathrm{Ti})(\mathrm{C}, \mathrm{N})$ precipitates mainly with TEM, using EDX measurements on thin foils or by indexing diffraction patterns ${ }^{23}$ ) on carbon extraction replicas. More recently, Craven et al. ${ }^{13)}$ described also the use of Parallel Electron Energy Loss Spectroscopy (PEELS) to determine the stoechiometry of precipitates. A PEELS spectrum from a precipitate in a microalloyed steel is compared to PEELS spectra taken from samples of commercial $\mathrm{NbC}$ and $\mathrm{NbN}$ powders. By using the spectrum from $\mathrm{NbN}$ powder as a background under the $\mathrm{C} \mathrm{K}$-edge, the $\mathrm{C}$ content of the precipitate can be compared with the $\mathrm{C}$ content in the $\mathrm{NbC}$ powder to calculate the exact fraction of $\mathrm{C}$ in the precipitate. In this work, an alternative route is used to determine the stoichiometry of the precipitates. The method uses X-ray diffraction on the filters, obtained from the selective dissolution, and has thus the advantage that the often time consuming and complicated thin foil preparation can be avoided or that also the C-stoichiometry can be determined, which is not the case for C-replicas. From the positions of the peaks in the intensity vs. $2 \theta$ spectrum, the lattice parameter, and thus the stoichiometry of the present precipitates could be determined. The method of measuring the filter, which only contains precipitates and not the as de- 


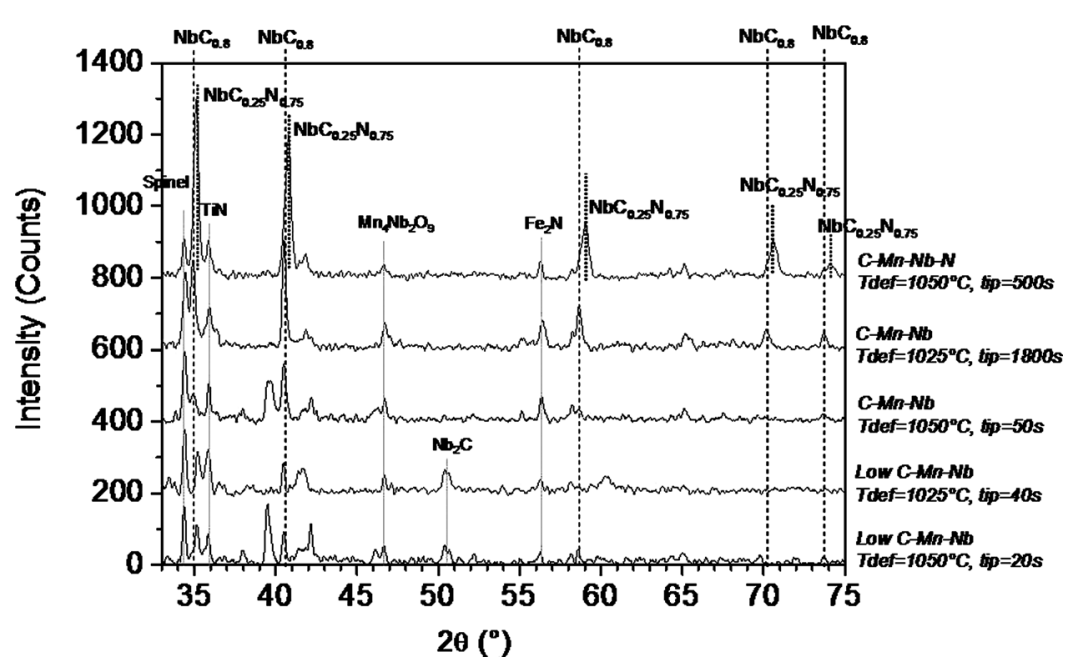

Fig. 6. Determination of the stoichiometry of the precipitates in three of the experimental steels by XRD measurements on ICP-MS filters. The filters were prepared from the quenched samples after double deformation. The deformation temperatures and interpass times are indicated on the graph.

formed material in a whole, i.e. precipitates and matrix, has the advantage that the peaks due to precipitation cannot overlap with matrix peaks and/or do not disappear in the background of the matrix. Five filters were measured and the results are presented in Fig. 6. A few complex precipitates are present on all five the filters. Further, evidence of $\mathrm{NbC}_{0.8}$ (cubic) precipitates with a lattice parameter of $0.445 \mathrm{~nm}$ was found in the $\mathrm{C}-\mathrm{Mn}-\mathrm{Nb}$ alloy, while in the lowC- $\mathrm{Mn}-\mathrm{Nb}$ alloy, at the measured temperatures these precipitates were absent. Some other peaks were found in the low $\mathrm{C}-\mathrm{Mn}-\mathrm{Nb}$ alloy only, i.e. the peak found at $50.3^{\circ}$. This peak was identified as hexagonal $\mathrm{Nb}_{2} \mathrm{C}$ and leads to a maximum fraction of $\mathrm{Nb}$ precipitated of $0.017 \mathrm{wt} \%$, which nicely agrees with the experimentally determined fraction of $0.016 \mathrm{wt} \%$ of $\mathrm{Nb}$ precipitated at $1025^{\circ} \mathrm{C}$. However, the presence of $\mathrm{Nb}_{2} \mathrm{C}$ only, cannot explain the experimentally determined amount of $0.03 \mathrm{wt} \%$ of $\mathrm{Nb}$ precipitated at $1000^{\circ} \mathrm{C}$ and at $950^{\circ} \mathrm{C}$. It is possible that at those lower temperatures also other $\mathrm{Nb}$-containing precipitates are present, such as $\mathrm{Fe}_{2} \mathrm{Nb}$ and $\mathrm{Fe}_{3} \mathrm{Nb}_{3} \mathrm{C} .^{21,22)}$ Due to a lack of thermodynamic data on these precipitates, it is at present not possible to accurately determine their solubility temperatures indicating their presence at 1000 and $950^{\circ} \mathrm{C}$. However, the plateau that strongly delays the recrystallization at 1000 and $950^{\circ} \mathrm{C}$, see Fig. 2(b), as well as the presence of $\mathrm{Nb}_{2} \mathrm{C}$ at higher temperatures, argue in favour of the existence of hyperstoichiometric $\mathrm{Nb} / \mathrm{C}$ precipitates and thus tends to confirm the experimentally determined weight fraction of $0.03 \mathrm{wt} \%$.

In the $\mathrm{C}-\mathrm{Mn}-\mathrm{Nb}-\mathrm{N}$ alloy the same peaks as in the $\mathrm{C}-\mathrm{Mn}-\mathrm{Nb}$ steel, i.e. $\mathrm{NbC}_{0.8}$ peaks, were found, although a little bit shifted towards higher angles when compared to the peaks in the $\mathrm{C}-\mathrm{Mn}-\mathrm{Nb}$ steel. This shift corresponds to a somewhat lower lattice parameter of $0.441 \mathrm{~nm}$ indicating the presence of more nitrogen in the precipitates. Knowing this lattice parameter, the $\mathrm{C}$ and $\mathrm{N}$ content in the precipitate could be determined according to Vegard's law. ${ }^{24)}$ According to this law, the lattice constant of a $\mathrm{NbCN}$ complex compound is expressed by Eq. (1) based on the assumption of Eq. (2):

$$
\begin{aligned}
& a_{\mathrm{NbCN}}=a_{\mathrm{NbN}} \cdot y_{\mathrm{N}}+a_{\mathrm{NbC}} \cdot y_{\mathrm{C}} \ldots \ldots \ldots \ldots \ldots \ldots \ldots \ldots \ldots \ldots \ldots \ldots \\
& y_{\mathrm{C}}+y_{\mathrm{N}}=1
\end{aligned}
$$

In which $y_{\mathrm{C}}$ and $y_{\mathrm{N}}$ represent the fraction of $\mathrm{C}$ and $\mathrm{N}$ in the sublattice of the precipitate according to the two-sublattice model. ${ }^{25)}$ The values of the lattice constants of $\mathrm{NbC}$ and $\mathrm{NbN}$ are taken from the work of Inoue et al. ${ }^{10)}$ In that way, a stoichiometry of $\mathrm{NbC}_{0.25} \mathrm{~N}_{0.75}$ was found from the X-ray spectrum. The found stoichiometries of the precipitates are in good agreement with the stoichiometries calculated under equilibrium conditions. This confirms the statement of Pandit et $a l^{26}$ ) who declared that deformation will greatly enhance the kinetics of precipitation but that the nature and the chemical composition of the precipitates is expected to remain the same as in the situation without deformation.

\subsection{Quantification of the Solute Drag Effect}

Equilibrium calculations as well as the experimentally determined precipitated weight fraction showed that for all the steels in this work, the maximum amount of $\mathrm{Nb}$ precipitated is rather low. The low amounts precipitated (maximum $0.06 \mathrm{wt} \% \mathrm{Nb}$ ) compared to the high total amount of $0.16 \mathrm{wt} \% \mathrm{Nb}$ in the steel, means that a rather high amount of $\mathrm{Nb}$ is still present in solution. This $\mathrm{Nb}$ in solution will cause an extra delay on the nucleation and growth stages of the recrystallization process. The retardation in the nucleation stage of the recrystallization is due to inhibition of dislocation climb, while the retardation in the growth stage is due to interference of the segregated $\mathrm{Nb}$ atom with the recrystallizing grain boundaries.

To quantify this solute drag effect it is necessary to define $\tau_{0.5}$, the normalized time to induce $50 \%$ softening, which is the real time to induce $50 \%$ softening, $t_{0.5}$, corrected by a grain size and a strain effect. Sellars ${ }^{2)}$ proposed the following relationship for $t_{0.5}$ in $\mathrm{C}-\mathrm{Mn}-\mathrm{Nb}$ steels:

$$
t_{0.5}=C \cdot d_{0}^{2} \cdot \varepsilon^{-4} \cdot \exp \left(\frac{Q_{\text {rex }}}{R T}\right)
$$

In which $d_{0}$ is the former austenitic grain size, $\varepsilon$ the true strain, $Q_{\text {rex }}$ the activation energy for static recrystallization, $T$ the temperature, $C$ a constant and $R$ the universal gas constant. The normalized time to induce $50 \%$ softening is then:

$$
\tau_{0.5}=t_{0.5} \cdot d_{0}^{-2} \cdot \varepsilon^{4}=C \cdot \exp \left(\frac{Q_{\text {rex }}}{R T}\right)
$$


This $\tau_{0.5}$ is only function of temperature for a specific steel. Thus from Eq. (4), the normalized time can be determined if $d_{0}, t_{0.5}$ and e are known. In this work, $d_{0}$ and $t_{0.5}$ were determined experimentally, see Table 2 and Table 3 , respectively; the value of $\varepsilon$ was 0.2 . It is usually found that the effect of solutes on $\tau_{0.5}$ follows an exponential law. ${ }^{27,28)}$ In the present case, it is:

$$
\tau_{0.5}=A \cdot \exp \left(\mathrm{SRP}_{0.5} \cdot[\mathrm{Nb}]_{\mathrm{sol}}\right) .
$$

Where $A$ is an experimental constant, $[\mathrm{Nb}]_{\text {sol }}$ the concentration of $\mathrm{Nb}$ in solution in weight percent and a solute retardation parameter $\left(\mathrm{SRP}_{0.5}\right)$ which can be used to quantify the solute effect at $50 \%$ of softening. The value of $\mathrm{SRP}_{0.5}$ can be determined by comparing $\tau_{0.5}$ of the $\mathrm{C}-\mathrm{Mn}-\mathrm{Nb}$ alloy at $1075^{\circ} \mathrm{C}$ with $\tau_{0.5}$ of the $\mathrm{C}-\mathrm{Mn}$ reference alloy at $1075^{\circ} \mathrm{C}$. At that temperature there is no evidence for precipitation in the $\mathrm{C}-\mathrm{Mn}-\mathrm{Nb}$ steel and the delay on $t_{0.5}$ is solely due to solute drag. To calculate $\mathrm{SRP}_{0.5}$ in that situation, Eq. (5) can be approximated as $^{29)}$ :

$$
\mathrm{SRP}_{0.5}=\frac{d \ln \tau_{0.5}}{d[\mathrm{Nb}]_{\mathrm{sol}}} \approx \frac{\ln \left(\tau_{0.5}^{1} / \tau_{0.5}^{2}\right)}{[\mathrm{Nb}]_{\mathrm{sol}}^{1}-[\mathrm{Nb}]_{\mathrm{sol}}^{2}}
$$

In which $\tau_{0.5}^{1}$ is the normalized $t_{0.5}$ for the $\mathrm{C}-\mathrm{Mn}-\mathrm{Nb}$ alloy at $1075^{\circ} \mathrm{C}$ and $\tau_{0.5}^{2}$ the normalized $t_{0.5}$ for the reference alloy at $1075^{\circ} \mathrm{C}$. Similarly $[\mathrm{Nb}]_{\text {sol }}^{1}$ and $[\mathrm{Nb}]_{\text {sol }}^{2}$ are the solute $\mathrm{Nb}$ concentration at $1075^{\circ} \mathrm{C}$ in the $\mathrm{C}-\mathrm{Mn}-\mathrm{Nb}$ alloy $(0.16 \mathrm{wt} \%$, see Table 3$)$ and in the reference alloy $(0 \mathrm{wt} \%)$, respectively. Substituting the $\tau_{0.5}$ into Eq. (6) and normalizing the solute $\mathrm{Nb}$ concentrations to $0.1 \mathrm{wt} \%, \mathrm{SRP}_{0.5}$ was calculated to be about 239 . This value is in close agreement with the value of 222 for $\mathrm{Nb}$ at $50 \%$ softening as reported by Jonas. ${ }^{30)}$ To determine whether the solute drag effect of $\mathrm{Nb}$ is stronger in the nucleation stage or in the growth stage of the recrystallization process, the solute retardation parameter at $5 \%$ softening, $\mathrm{SRP}_{0.05}$, was also calculated. Therefore, in Eq. (6) $\tau_{0.5}^{1}$ and $\tau_{0.5}^{2}$ were replaced by $\tau_{0.05}^{1}$ and $\tau_{0.05}^{2}$ respectively. $\tau_{0.05}^{1}$ is the normalized time at $5 \%$ softening for the $\mathrm{C}-\mathrm{Mn}-\mathrm{Nb}$ alloy at $1075^{\circ} \mathrm{C}$ and $\tau_{0.05}^{2}$ the normalized time at $5 \%$ softening for the $\mathrm{C}-\mathrm{Mn}$ reference alloy at $1075^{\circ} \mathrm{C}$. The solute retardation parameter at $5 \%$ softening was found to be 177 . This value is remarkably smaller than the value of 239 found at 50\% softening, indicating that $\mathrm{Nb}$ in solution mainly delays the migration of grain boundaries, i.e. the grain growth stage, and to a lesser extent the formation of new dislocation free nuclei, i.e. the nucleation stage of the recrystallization process.

With the calculated value of $\mathrm{SRP}_{0.5}$, the ratio between the time for $50 \%$ softening due to solute drag of $\mathrm{Nb}$ in the $\mathrm{C}-\mathrm{Mn}-\mathrm{Nb}$ steel and the time for $50 \%$ softening in the reference steel was calculated at lower temperatures. This ratio was found to vary between 8 and 8.8 in the temperature range from 1075 to $1000^{\circ} \mathrm{C}$. For the solute drag effect of $\mathrm{Nb}$ in the lowC- $\mathrm{Mn}-\mathrm{Nb}$ alloy, comparable ratios between 8.7 and 9 were found. The limited differences between those ratios make it possible to construct the dashed line in Fig. 7 as a parallel to the $t_{0.5}$ line of the $\mathrm{C}-\mathrm{Mn}$ reference steel. This dashed line represents the retardation on the recrystallization due to solute drag of $\mathrm{Nb}$ in solution. This so called "Nb solute drag line" allows us to quantify the magnitude of the solute drag and the precipitation effect directly from a softening-time-temperature diagram.

The $\mathrm{C}-\mathrm{Mn}-\mathrm{Nb}-\mathrm{N}$ steel deviates from the $\mathrm{Nb}$ solute drag line at all temperatures tested in this work. It is concluded that the retardation of the recrystallization behavior in this steel at all temperatures is caused by a combination of

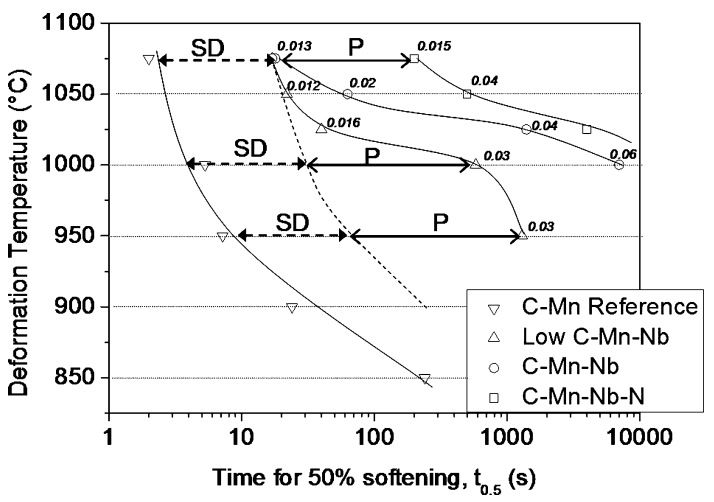

Fig. 7. Softening-time-temperature diagrams for the four experimental steels. (Plotted is the time for $50 \%$ softening and the corresponding weight fraction of precipitated $\mathrm{Nb}$ (in italics), see also Table 3; $\mathrm{SD}=$ solute drag, $\mathrm{P}=$ precipitation).

solute drag and precipitation. In Fig. 7, the former is indicated as SD and the latter as P. While on a logarithmic scale the magnitude of the solute drag effect is almost constant over the temperature range, the magnitude of the precipitation effect seems to increase with decreasing temperatures. Equilibrium calculations as well as XRD measurements showed that, at $1075^{\circ} \mathrm{C}$ and at $1050^{\circ} \mathrm{C}, \mathrm{NbN}$ precipitates are responsible for the delay, while at $1025^{\circ} \mathrm{C}$ it is mainly $\mathrm{NbC}$. The fact that at $1025^{\circ} \mathrm{C}$ the $t_{0.5}$ curve of the $\mathrm{C}-$ $\mathrm{Mn}-\mathrm{Nb}-\mathrm{N}$ steel approaches the $t_{0.5}$ curve of the $\mathrm{C}-\mathrm{Mn}-\mathrm{Nb}$ steel, where there are only $\mathrm{NbC}$ precipitated, confirms this. The $\mathrm{C}-\mathrm{Mn}-\mathrm{Nb}$ steel starts to deviate from the $\mathrm{Nb}$ solute drag line at temperatures of $1050^{\circ} \mathrm{C}$. ICP-MS measurements verified that there was already a small amount of $\mathrm{Nb}$ precipitated at that temperature which is probably insufficient to cause a plateau in the softening curve. In the lowC-Mn-Nb steel, the deviation from the $\mathrm{Nb}$ solute drag line starts at $1025^{\circ} \mathrm{C}$ which is agreement with the plateau observed in Fig. 2(b). Furthermore, it can be noticed that in this alloy, at $1000^{\circ} \mathrm{C}$ the main part of the delay on $t_{0.5}$ is caused by a precipitation effect. TEM measurements already confirmed the presence of small $\mathrm{NbC}$ precipitates at $1000^{\circ} \mathrm{C}$, see Fig. 5(a). At $950^{\circ} \mathrm{C}$, the precipitation effect appears to become smaller again. According to the ICP-MS measurements no extra precipitates had been formed by lowering the temperature from 1000 to $950^{\circ} \mathrm{C}$. The amount of $\mathrm{Nb}_{\text {prec }}$ stays $0.03 \mathrm{wt} \%$ which is in agreement with the equilibrium value at that temperatures. TEM measurements at $950^{\circ} \mathrm{C}$ show that the precipitates had grown at the expense of certain other precipitates that had been dissolved. The average particle size at $950^{\circ} \mathrm{C}$ is $40 \mathrm{~nm}$, see Fig. 5(b). From the Zener pinning formula, ${ }^{31)}$ it can be seen that these larger particles are less effective in pinning boundaries of the recrystallized grains. The Zener pinning force is given by:

$$
F_{\mathrm{P}}=\frac{3 \cdot \gamma_{\mathrm{GB}} \cdot F_{\mathrm{v}}}{2 \cdot r}
$$

Where $\gamma_{\mathrm{GB}}, F_{\mathrm{v}}$ and $r$ represent the grain boundary energy (usually $0.75 \mathrm{~J} / \mathrm{m}^{2}$ in austenite), the precipitate volume fraction and the average precipitate radius, respectively. An increase of the volume fraction of precipitates increases the total driving pinning force, while coarsening at constant volume fraction decreases the pinning force. For the lowC-Mn-Nb alloy at times of $50 \%$ softening, pinning forces of $2.3 \cdot 10^{4} \mathrm{MPa}$ and $8.4 \cdot 10^{3} \mathrm{MPa}$ were found for 
deformation temperatures of $1000^{\circ} \mathrm{C}$ and $950^{\circ} \mathrm{C}$, respectively. These pinning forces are compared to the driving forces for recrystallization. When the recovery effect during isothermal holding is neglected, this driving force is equal to the stored energy after deformation ${ }^{32)}$.

$$
F_{\mathrm{R}}=\frac{1}{2} \cdot \rho \cdot \mu \cdot b^{2}
$$

In which $\rho$ is the dislocation density after deformation $\left(\sim 3 \cdot 10^{14} \mathrm{~m}^{-2}\right), \mu$ the shear modulus $\left(\sim 4 \cdot 10^{4} \mathrm{MPa}\right)$ and $b$ the magnitude of the Burgers vector $\left(\sim 2.53 \cdot 10^{-10} \mathrm{~m}\right)$. For the lowC- $\mathrm{Mn}-\mathrm{Nb}$ steel, $F_{\mathrm{R}}$ is found as $4 \cdot 10^{5} \mathrm{MPa}$. The driving force for recrystallization is thus one order of magnitude higher than the pinning force at $1000^{\circ} \mathrm{C}$ and almost 2 orders of magnitude at $950^{\circ} \mathrm{C}$ at times of $50 \%$ softening. This agrees well with the results from Fig. 2(b): at times of $50 \%$ softening, i.e. $580 \mathrm{~s}$ at $1000^{\circ} \mathrm{C}$ and $1300 \mathrm{~s}$ at $950^{\circ} \mathrm{C}$, no plateau is found or thus the recrystallization rate is different from zero.

Although the precipitate sizes, reported in this work, are almost one order of magnitude larger than the ones Hutchinson $^{6}$ ) assumes for the calculations in his work, the tendency is similar: The dominant mechanism in retarding the austenite recrystallization changes from precipitation, at temperatures just below the solubility temperature, to solute drag, at precipitate coarsening temperatures.

\section{Conclusions}

In this contribution, the recrystallization behavior was studied extensively by multideformation tests and isothermal double deformation tests and shown to depend strongly on the precipitation state of the material. The results can be summarized as follows:

(1) The addition of $0.17 \mathrm{wt} \% \mathrm{Nb}$ on the recrystallization behavior was compared by multideformation torsion tests and double hit compression tests. Both testing methods gave consistent results and showed that $\mathrm{Nb}$ strongly delays the recrystallization. By adding $0.17 \mathrm{wt} \% \mathrm{Nb}$ to the reference alloy, $T_{\mathrm{nr}}$ was raised by $73^{\circ} \mathrm{C}$. With the same amount of $\mathrm{Nb}$ but a drastic decrease of $\mathrm{C}, T_{\mathrm{nr}}$ is raised by only $43^{\circ} \mathrm{C}$. This result indicates that $\mathrm{Nb}$ as precipitate is more effective in retarding the recrystallization than $\mathrm{Nb}$ in solid solution, although it has to be noticed that also in the lowC-Mn-Nb alloy (with only $11 \mathrm{ppm}$ of $\mathrm{C}$ ) the presence of a small fraction of $\mathrm{NbC}$ was found resulting in an extra delay of the recrystallization.

(2) Adding extra $\mathrm{N}$ to a $\mathrm{C}-\mathrm{Mn}-0.16 \mathrm{wt} \% \mathrm{Nb}$ steel does not increase $T_{\mathrm{nr}}$ but significantly influences the recrystallization behavior in a double deformation test which it delays strongly by the precipitation of fine $\mathrm{NbN}$ particles. These $\mathrm{NbN}$ particles were not found in the $\mathrm{C}-\mathrm{Mn}-\mathrm{Nb}$ steel with only $20 \mathrm{ppm}$ of $\mathrm{N}$.

(3) Thermodynamic calculations assuming a phase equilibrium between $\gamma$ and $(\mathrm{Nb}, \mathrm{Ti})(\mathrm{C}, \mathrm{N})$ were found to give a good approximation for the real precipitation state in a microalloyed steel under deformation conditions. The precipitated fraction as well as the stoichiometry of the precipitates were in good agreement, especially for the $\mathrm{C}-\mathrm{Mn}-\mathrm{Nb}$ and for the $\mathrm{C}-\mathrm{Mn}-\mathrm{Nb}-\mathrm{N}$ alloy, with the results from ICP-MS and XRD measurements, respectively. Both experimental results and calculations show that TiN predominantly forms at very high temperatures and that $\mathrm{NbC}$ or $\mathrm{Nb}(\mathrm{C}, \mathrm{N})$ precipitate at lower temperatures.
(4) It was proven that softening-time-temperature diagrams contain a lot of information on the precipitation state of the material. By drawing the solute drag line, the precipitation start temperature is found as the temperature at which $t_{0.5}$ starts to deviate from this solute drag line. By comparing the distance between the $t_{0.5}$ of a reference alloy and the solute drag line with the distance between the solute drag line and the $t_{0.5}$ of a microalloyed steel, a quantification of the solute drag effect and the precipitation effect can be made at all temperatures. Furthermore, the temperature where the precipitation effect becomes again smaller is an indication for the temperature at which precipitate coarsening starts.

\section{REFERENCES}

1) T. M. Maccagno, J. J. Jonas, S. Yue, B. J. McCrady, R. Slobodian and D. Deeks: ISIJ Int., 34 (1994), 917.

2) C. M. Sellars: Proc. of Int. Conf. on Hot Working and Forming Processes, ed. by C. M. Sellars and G. J. Davies, Met. Soc., London, (1980), 3 .

3) J. G. Speer and S. S. Hansen: Metall. Trans. A, 20A (1989), 25.

4) S. F. Medina, A. Quispe, P. Valles and J. L. Banos: ISIJ Int., 39 (1999), 913.

5) M. J. Luton, R. Dorvel and R. A. Petkovic: Metall. Trans., 11 (1980), 411.

6) C. R. Hutchinson, H. S. Zurob, C. W. Sinclair and Y. J. M. Brechet: Scr. Mater, 59 (2008), 635.

7) R. Coladas, J. Masounave and J. P. Bailon: Proc. Int. Conf. on the Hot Deformation of Austenite, TMS-AIME, New York, (1977), 341.

8) M. G. Akben, I. Weiss and J. J. Jonas: Acta Metall., 29 (1981), 111.

9) H. L. Andrade, M. G. Akben and J. J. Jonas: Metall. Trans. A, 14A (1983), 1967

10) K. Inoue, N. Ishikawa, I. Ohnuma, H. Ohtani and K. Ishida: ISIJ Int., 41 (2001), 175

11) H. Zou and J. S. Kirkaldy: Metall. Trans. A, 23A (1992), 651.

12) Z.-K. Liu: Scr. Mater., 50 (2004), 601

13) A. J. Craven, K. He, L. A. J. Garvies and T. N. Baker: Acta Mater, 48 (2000), 3857.

14) A. Gräber and K. Pöhlandt: Steel Res., 61 (1990), 212

15) D. Q. Bai, S. Yue, W. P. Sun and J. J. Jonas: Metall. Trans. A, 24A (1993), 2151.

16) M. Gomez, S. F. Medina and P. Valles: Proc. of 2nd Int. Conf. on Thermomechanical Processing of Steels, Liège, Belgium, (2004), 157.

17) A. I. Fernandez, B. Lopez and J. M. Rodriguez-Ibabe: Scr. Mater., 40 (1999), 543.

18) G. Li, T. M. Maccagno, D. Q. Bai and J. J. Jonas: ISIJ Int., 36 (1996), 1479.

19) A. I. Fernandez, P. Uranga, B. Lopez and J. M. Rodriguez-Ibabe: ISIJ Int., 40 (2000), 893.

20) F. B. Pickering: Ttitanium Technology in Microalloyed Steels, ed. by T. N. Baker, The Institute of Materials, London, (1994), 10.

21) G. M. Sim, J. C. Ahn, S. C. Hong, K. J. Lee and K. S. Lee: Mater. Sci. Eng., 396 (2005), 159

22) V. Kuzucu, M. Aksoy, M. H. Korkut and M. M. Yildirim: Mater. Sci. Eng., 230 (1997), 75.

23) C. Klinkenberg, K. Hulka and W. Bleck: Steel Res., 75 (2004), 744.

24) A. R. Denton and N. W. Ashcroft: Phys. Rev. A, 43 (1991), 3161

25) M. Hillert and L. I. Staffansson: Acta Chem. Scand., 24 (1970), 3618 .

26) A. Pandit, A. Murugaiyan, A. Saha Podder, A. Haldar, D. Bhattacharjee, S. Chandra and R. K. Ray: Scr. Mater., 53 (2005), 1309.

27) C. M. Sellars and J. H. Beynon: Proc. Conf. on High Strength Low Alloy Steels, ed. by D. P. Dunne and T. Chandra, ASM, Ohio, USA, (1985), 142

28) J. C. Herman, P. Messien and T. Gredary: Proc. Conf. on ThermoMechanical Processing of Microalloyed Austenite, ed. by A. J. DeArdo, G. A. Ratz and P. J. Wray, AIME, Warrendale, P.A., USA, (1982), 655.

29) W. J. Liu and M. G. Akben: Can. Metall. Q., 26 (1987), 145.

30) J. J. Jonas: Proc. Conf. on High Strength Low Alloy Steels, ed. by D. P. Dunne and T. Chandra, ASM, Ohio, USA, (1984), 80.

31) C. Zener and C. S. Smith: Trans. Am. Inst. Min. Eng., 175 (1948), 15

32) H. S. Zurob, Y. Brechet and G. Purdy: Acta Mater, 49 (2001), 4183. 